\title{
PRIMARY DIAGNOSTICS OF TEACHERS OF SPECIAL DISCIPLINES OF TECHNICAL COLLEGE
}

\author{
Svitlana Sadovenko \\ Postgraduate Student, Zaporizhzhya National University, Ukraine \\ e-mail: svetlana.sad71@gmail.com,orcid.org/0000-0003-3758-2051 \\ Agnieszka Szpak \\ Ph.D., Polonia University in Czestochowa, Interdisciplinary Faculty, Poland \\ e-mail: aszpak@ap.edu.pl, orcid.org/0000-0001-7193-6728
}

\begin{abstract}
Summary
The article raises the issue of readiness for teaching in the Ukrainian Technical College of specialists who do not have pedagogical education. It is determined that the motivating factor is an important factor influencing the work of a young teacher, the formation and development of future professionals, and the problem of determining the readiness of a specialist with engineering education to teach, his motivation for a new activity, ability to acquire knowledge and skills is extremely relevant and needs attention from the head of scientific and methodological work. It is proposed to introduce the primary scientific and diagnostic development of the mechanism of differentiated psychological and pedagogical influence on teachers of special disciplines of the technical college, which will determine the types of teachers, taking into account the level of their motivation for teaching. The algorithm of application of methods, including author's, is considered, methodical recommendations concerning their application, calculation, use of results of research are given. It is concluded that the application of primary scientific and diagnostic development of the mechanism of differentiated psychological and pedagogical influence in the technical college will help to adjust group and individual scientific and methodical work with beginning teachers and teaching staff as a whole, to plan further stages of development of psychological and pedagogical competence.

Keywords: motivation, pedagogical diagnostics, scientific and methodical work, psychological and pedagogical training, teacher of special disciplines
\end{abstract}

DOI: https://doi.org/10.23856/4215

\section{Introduction}

During the period of reforming the entire system of Ukrainian education, the issue of high-quality staffing of the educational process becomes especially important. However, institutions of professional higher education have their own specific features: their students are usually minors who are not always ready for the realities of college education, and teachers of special disciplines are usually people who do not have pedagogical education and any previous psychology-pedagogical training. Studying the experience of educational systems of other countries, we can conclude that there are different approaches to solving this problem.

While being on refresher courses (internships) at the University of Social Sciences Vincent Paul in Lublin (Republic of Poland, December 2019), had the opportunity to get acquainted with the system and structure of education in general in this country, as well as educational and methodological features of educational institutions of the technical level. 
The topic of the internship «Innovative aspects of management of modern educational institutions» included meetings with heads of different levels and types of educational institutions. It turned out that a university graduate does not have the right to work in a technical school, and even more so in a school or lyceum, because working with minors and students requires pedagogical education. In order for a future teacher to be able to get a job as a teacher, he must obtain additional pedagogical education. If you have a university degree in any specialty, the period of study will be one and a half years. That is, knowledge of pedagogy, age psychology, teaching methods are understood not as desirable for the teacher, including special disciplines, but as mandatory, without which he will not have the right to engage in pedagogical activities with minors. As there is no such requirement in Ukraine, it creates a number of difficulties.

The biggest problems arise more often in the initial stages of pedagogical activity of teachers of special disciplines, but the analysis of the level of teaching and work experience shows that even more experienced teachers do not always have sufficient tools, knowledge and skills to choose optimal forms and methods of teaching, educational work with students, communicative techniques. This factor prevents further professional growth, raising the level of qualification and teaching, causes many pedagogical mistakes, complicates interaction with colleagues and students.

Therefore, the problem of determining the readiness of a specialist with engineering education to teach, his motivation for a new activity, the ability to acquire knowledge and skills, without which to succeed as a teacher will be difficult. The task of the head of scientific and methodical work of the technical college is to timely primary diagnosis of teachers, the study of the teaching staff on the issue of motivation to work in an institution of professional higher education.

\section{Research of the problem of pedagogical motivation}

Issues of motivation, motivation for the type of activity or process have been the subject of search and discussion of scientists in different periods of the history of science. Since antiquity, the phenomenon of motivation has been studied by scientists in various fields from a cultural point of view, taking into account psychological aspects, the economic component of this complex process. We observe many studies of the study of professional motivation of teachers in the works of Ukrainian scientists. For example, «Ukrainian pedagogical dictionary» $\mathrm{S}$. Goncharenko defines motivation as a system of motives or stimuli that motivates a person to specific forms of activity or behavior. Motives can be ideas and ideas, feelings and experiences that express the material or spiritual needs of man. The same activity can be carried out for different reasons (Goncharenko, 1997). Motivation is the most important factor in improving the efficiency of activities, the process of personal interest in solving the actual problems, tasks and achieving the desired goals (Vilunas, 1979:243-244), and the management of motivation of professional development of the teacher - a complex process that involves the creation of optimal conditions for the development of professional and pedagogical competence (Cisco, 2018).

Researchers, whose works are devoted to the problems of motivation in the teacher's activity, note the importance of such factors as pedagogical orientation (pedagogical orientation), personal orientation to pedagogical activity. In the works of M. Opolska the essence of professional orientation as a manifestation of personality inclination and suitability for socially significant activities, the presence of dominant professional motives, interests, goals and values, a stable positive attitude to reality, society, professional activity (Opolska, 2009). 
O. Dubaseniuk, noting one of the characteristics of the teacher's personality, speaks of a person's personal orientation to teaching (Dubaseniuk, 2012:147). Orientation implies a lasting interest in the personalities of those you teach, the ability to pedagogical creativity, the tendency to engage in this type of activity, awareness of their abilities. The main motive of a purely pedagogical orientation is the interest in the content of pedagogical activity. Therefore, to determine the extent to which the beginning teacher is focused and motivated to teach, is a priority for the college methodologist.

In the context of the specified purpose of the article is definition of algorithm of introduction of primary scientific and diagnostic development of the mechanism of the organization of the differentiated psychological and pedagogical influence on teachers of special disciplines of technical college.

Psychological and pedagogical diagnostics is an extremely important and complex element of scientific and methodological work, without which the development and effective functioning of the system itself will not have positive results. Application of primary scientific and diagnostic development of the mechanism of organization of differentiated psychological and pedagogical influence on teachers of special disciplines of technical college at the initial stage of their activity will allow to form idea of professional level of teacher, his motivation for work, readiness for teaching, ability to collective forms of cooperation with pedagogical and students.

\section{Algorithm for implementing scientific and diagnostic development}

One of the forms of scientific and methodical work of the Separate structural subdivision of the Dnieper Professional College of Engineering and Pedagogy of the State Higher Educational Institution «Ukrainian State University of Chemical Technology» is the "School of Young Teachers», headed by a college methodologist.

The first meeting by appointment is introductory, but very important and determines the directions and prospects for further scientific and methodological work. Teachers get acquainted with the head of the «School», with each other, inform them about the purpose and purpose of future meetings, topics and work plan. If the leader manages to create a friendly and relaxed atmosphere of the event, encourage participants to talk, interest, encourage cooperation and dialogue, it will mean that the next meeting members of the «School of Young Teachers» will come with pleasure and without coercion.

However, it should be understood that the Methodist is not dealing with adolescents, not just students, but with adults, individuals, professionals in their field, each of whom has experience, achievements, understanding of their profession and the role of disciplines that teaches in the formation of future professionals. Not all of them will want to be in the category of students again, to recognize that for teaching only special knowledge of the subject will not be enough, and pedagogical work, which constantly requires self-education, improvement, formation and development of new psychological and pedagogical competencies, the same serious work, as well as work in production. Therefore, it is advisable at the first meeting of the «School» to conduct an initial survey of teachers, which will help to form a first impression of the contingent of students, determine the level of motivation for teaching and identify types of teachers depending on the results.

The form of the survey may be different. It depends on the technical capabilities of teachers and their level of digital education. It makes sense to find out in advance, so that, firstly, not to waste time at the meeting, and secondly, not to force colleagues to justify themselves and explain their position in the presence of outsiders. The best option is to give the teacher the 
opportunity to choose how he will take the questionnaire. It is easier for someone to fill in the forms in the methodical office, consulting with the methodologist regarding the questionnaire questions. Someone will want to do it at home so that they can think about the answers by filling out electronic questionnaires. The main thing is that this survey takes place and feedback is established.

The first questionnaire is an author's development and is used to determine different types of teachers depending on the degree of their motivation to teach.

Questionnaire of a young teacher

1. Do you want to go to work?

2. Do you always achieve the goal of the lesson?

3. Will you be able to self-analyze the lesson?

4. Do you have mutual understanding with students?

5. Are you familiar with periodicals, online publications that contain materials on pedagogy, psychology, problems of education?

6. What type of lessons do you most often teach?

7. What innovative educational technologies do you know? Elements of which do you use in your activities?

8. What issues would you like to discuss with the college methodologist, with the head of the department, deputy directors, with the director of the college?

9. What issues do you propose to discuss at the meetings of the «School of Young Teachers»?

The questionnaire consists of two blocks. The first block (items 1-5) contains questions to which the teacher has 3 possible answers. Depending on the chosen option, the number of points is accrued. The answer «yes» is estimated at 3 points, the option «I can not answer» - at 2 , «no», respectively, at 1 point. When using the Google-form, the teacher chooses the answer, the number of points for which is calculated automatically.

The second block (questions 6-9) provides a detailed answer, the number of points for each from 0 to 3 . Since for ease of use it is recommended to use Google-form, this block of the questionnaire methodologist or surveyor, processed and evaluated for each respondent separately. The number of points is calculated depending on the completeness of the answer, the teacher's interest in further cooperation and dialogue, his sincerity.

The answers to these questions also contain a psychological aspect, they demonstrate how much a person is ready to make contact. After processing the answers and counting the number of points for each respondent, three types of teachers are formed in terms of their motivation for pedagogical work (maximum number of points - 27): Type I - 5-9 points, Type II 10-18, Type III - 19-27.

It is always noticeable when the respondent is reluctant to answer, gives formal, standard answers or does not answer at all. This means that he does not want to strain too much, these problems are not interesting to him or he does not consider them problems for himself personally, even to make a good impression is unimportant for him. He participates in the survey only because he was forced to do so, neither the result nor the number of points scored for him are significant, because he already considers himself a professional. Such teachers can behave defiantly, show their self-confidence, even aggression. The main motive of their position and behavior: «You can not teach me anything useful, because you are not an expert in my field».

Number of points - 5-9 (conditional name of the first type - «indifferent»).

The second category of teachers are those who have not yet decided on their future teaching activities, nor on how much they want to develop in this profession, or are interested in achieving high results as teachers. They usually respond neutrally, adhering to the 
«golden mean». The answers provided are short, vague, may be borrowed somewhere, not your own. That is, the teacher is open and does not show indifference to questions, so as not to draw special attention to himself, but also does not show interest. Such teachers do not take initiatives, try to remain silent during methodical activities, during a conversation or questionnaire try to guess the «correct» answer that would satisfy the management and the interlocutor.

Number of points 10-18 (type III - «inert»).

And the last category of respondents - teachers who came to the school consciously, they made this choice of their future carefully, realizing that to achieve the result you need to make an effort. They are ready to cooperate, they are interested in the process of acquiring new knowledge and skills, they are active, willing to engage in dialogue and discussion. Their answers are detailed, the questions proposed for discussion (paragraphs 8-9) are considered, reflect their understanding of the educational process, pedagogical problems, aimed at future self-improvement.

Number of points 19-27 (type III - «interested»).

The questionnaire used as follows is the method of «Teacher's satisfaction with the chosen profession» and is a modification of A. Reana Methods B. Yadov, H. Kuzmina (Bordovskaya, Rean, 2000). It has only three questions (scales), each of which offers five possible answers. This technique determines the index of teacher satisfaction with the teaching profession, it is easy to use, the results are easy to calculate, you can analyze for each respondent and the cycle commissions, if necessary - to determine the overall index of satisfaction of the teaching staff as a whole.

The result obtained should be compared with the standard:

-from 1 to 1.5 points - satisfaction with the profession is very low (dissatisfaction);

-from 1.6 to 2.5 points - satisfaction is lower than average;

-from 2.6 to 3.5 points - average satisfaction;

-from 3.6 to 4.5 points - satisfaction is above average;

-from 4.6 to 5 points - satisfaction with the profession is high.

We consider for convenience of calculation to distribute the received results on the types of teachers defined in preliminary questionnaire as follows:

And type - «indifferent» - from 1 to 2.5 points;

Type II - «inert» - from 2.6 to 4.5 points;

Type III - «interested» - from 4.6 to 5 points.

The last questionnaire proposed at the first meeting is the method of K. Zamfir, modified by A. Reana «Motivation of professional activity» (Rean, Bordovskaya, Rozum, 2005). The technique is used to diagnose the motivation of professional teaching. The methodology is based on the concept of internal and external motivation. It is known that with intrinsic motivation, the activity is significant for the individual itself. If the motivation of professional activity is based on the desire to meet other needs that are not directly related to the activity itself (motives of social prestige, salary, etc.), then in this case it is an external motivation. At the same time, external motives are differentiated into external positive and external negative.

Working with this technique is more painstaking, requires attention from the organizer of the questionnaire, analysis of the results for each respondent. An indicator of the expressiveness of each type of motivation will be a number that ranges from 1 to 5 (possibly fractional). On the basis of the received results the motivational complex of the person is defined. Motivational complex is a type of relationship of three types of motivation: internal motivation, external 
positive motivation and external negative motivation. The best (optimal) motivational complexes include the following types of combinations:

1. internal motivation is more than external positive, which, accordingly, is more than external negative;

2. internal motivation is equal to the indicators of external positive, which is greater than external negative.

The worst motivational complex is the ratio when the external negative motivation is greater than the external positive, and internal motivation has the lowest value of the three. When interpreting, it is necessary to take into account not only the type of motivational complex, but also the extent to which one type of motivation exceeds another in the degree of expressiveness, taking into account not only the comparative aspect «more or less» but also the quantitative indicator for each type of motivation.

After a careful analysis of the data, it is advisable to group the results according to the three types of teachers identified in previous questionnaires: «indifferent», «inert», «interested», taking into account the ratio of indicators and comparison of motivation types for each teacher. The obtained results are compared with the previous data and the arithmetic mean for each respondent is calculated, determining the affiliation to one of the three types of teachers. If the results are ambiguous and the teacher in three questionnaires showed different results (belonging to the type), it is advisable to use individual forms of work (conversation, consultation, etc.) to specify and clarify the diagnostic data.

It should be borne in mind that the information obtained during the questionnaire is purely confidential, the number of points, the teacher's affiliation to the type specified in the questionnaires cannot be made public, much less discuss with members of the administration the facts that characterize the respondent negatively. It is possible to include the questions offered by teachers for discussion at meetings of cycle commissions, «School of the young teacher on experience», pedagogical council depending on their orientation and significance. The main purpose of the questionnaire at this stage for the Methodist - to adjust the forms of further scientific and methodological work in the college in general and the «School of young teachers», to plan individual work with beginning teachers, taking into account the results of the study.

\section{Conclusions}

Thus, the application of primary scientific and diagnostic development of the mechanism of differentiated psychological and pedagogical influence will help to adjust group and individual scientific and methodical work with the teaching staff, to plan further stages of development of psychological and pedagogical competence of teachers of special disciplines. The next step is to recommend the introduction of a special training course in the methodological work of the technical college, which will contribute to the acquisition of necessary, basic knowledge and skills by young teachers of basic pedagogy, age psychology, teaching methods. The general program of the special course, which is designed for all students of the «School», should be adjusted in accordance with the types of teachers determined by the results of the diagnosis.

In our opinion, it is advisable to develop guidelines and use such forms of scientific and methodological work that will be most effective for a particular type of teachers, determined by the results of the study. This will optimize the work of teachers during the mastering of the special course program and, accordingly, will increase their learning effectiveness. 


\section{References}

Bordovskaya N.V., Rean A.A. (2000) Pedagogika. Uchebnik dlya vuzov [Pedagogy. Textbook for universities]. Sankt-Peterburg: Piter. [in Russia]

Vilyunas V.K. (1979) Emotsii i situativnoye razvitiye motivatsii. Razvitiye ergonomiki v sisteme dizayna: tezisy dokl. konf. [Emotions and situational development of motivation. Development of ergonomics in the design system: abstracts. conf.] Borzhomi, pp. 243-244. [in Russia]

Honcharenko S.U. (1997) Ukrayins'kyy pedahohichnyy slovnyk [Ukrainian pedagogical dictionary]. Kyyiv: Lybid'. [in Ukrainian]

Dubasenyuk O.A., Antonova O.YE. (2012) Metodyka vykladannya pedahohiky: navch. posib. 2-he vyd., dop. [Methods of teaching pedagogy: textbook. way. 2nd ed]. Zhytomyr: ZHDU im. I. Franka. [in Ukrainian]

Opol's'ka M. V. (2009) Formuvannya humanistychnoyi spryamovanosti maybutnikh menedzheriv-ekonomistiv u protsesi profesiynoyi pidhotovky [Formation of humanistic orientation of future managers-economists in the process of professional training] (PhD Thesis), Kyyiv. [in Ukrainian]

Rean A.A., Bordovskaya N.V., Rozum S.I. (2005) Psikhologiya i pedagogika [Psychology and pedagogy]. Sankt-Peterburg: Piter. [in Russia]

Sysko N. M. (2018) Motyvatsiya yak vazhlyvyy chynnyk neperervnoho profesiynoho rozvytku vykladacha zakladu profesiynoyi osvity [Motivation as an important factor of the continuous professional development of a teacher of vocational education]. [in Ukrainian]. Retrieved from: http:file://C:/Users/1/Downloads/151597-327368-1-SM\%20(1).pdf DOI:10.32626/2 307-4507.2018-24.177-180 